\title{
Kualitas Penerapan Higiene Sanitasi (Studi Kasus: Kantin Universitas X Lamongan)
}

\author{
Moh. Syamsudin Hasan', Marsha Savira Agatha Putri ${ }^{2 *}$, Rizky Rahadian Wicaksono² \\ ${ }^{1}$ Mahasiswa Program Sarjana Kesehatan Lingkungan Universitas Islam Lamongan \\ ${ }^{2}$ Dosen Program Studi Kesehatan Lingkungan Universitas Islam Lamongan \\ *Corespondence author: marshasavira@unisla.ac.id, Telp: 085748804233
}

Received: 13 Agustus 2020; Accepted: 29 September 2020; Published: 29 September 2020

\begin{abstract}
Abstrak
Higiene sanitasi adalah upaya untuk mengendalikan faktor risiko terjadinya kontaminasi terhadap makanan, baik yang berasal dari bahan makanan, orang, tempat dan peralatan agar aman dikonsumsi. Higiene dan sanitasi tidak dapat dipisahkan satu dengan yang lain. Apabila higienenya sudah baik dengan mau mencuci tangan, akan tetapi sanitasinya tidak mendukung karena tidak tersedia akses air bersih yang tersedia dan tidak mencukupi, sehingga fungsi dan tujuan mencuci tangan tidak efektif. Kualitas Higiene sanitasi dapat di pengarui oleh dua faktor yaitu faktor lingkungan dan faktor penjamah makanan. Faktor penjamah makanan salah satu faktor yang berpengaruh karena manusia bisa berupa vektor pembawa bakteri yang bisa mencemari dan mengontaminasi suatu makan. penelitian ini bersifat penelitian kuantitatif deskriptif analitik. Desain yang digunakan dalam penelitian ini adalah cross sectional. Data yang digunakan adalah data primer yang didapat melalui kuesioner dan observasi.
\end{abstract}

Kata Kunci: Higiene Sanitasi, Kualitas Higiene Sanitasi, Faktor Penjamah Makanan

\section{Pendahuluan}

kondisi kantin khususnya di lingkungan kampus jarang sekali diperhatikan oleh pengelolanya. Aspek makanan yang dijual, para penjamah makanan yang dalam hal ini adalah penjual makanan itu sendiri, petugas kebersihan serta aspek sanitasi dan pengelolaan limbahnya. Konsumen yang begitu banyak, membuat para penjamah makanan lalai untuk menjamin kehigienitasan makanan dan minuman yang dijual. Banyak dari penjual makanan hanya menjual 
makanan yang dirasa disukai oleh banyak konsumen tanpa mementingkan aspek nilai gizi yang ada dalam makanan. Selain itu, fasilitas pada kantin kurang tempat cuci tangan ataupun tempat untuk membuang sampah makanan (Febriyanto, 2016).

Berdasarkan hasil observasi langsung dan survei awal yang sudah dilakukan di tujuh kantin kampus Universitas X Lamongan, masih dijumpai proses pengelolaan makanan yang tidak baik, penjual masih meletakkan makanan matang tanpa diberi penutup selain itu,kantin tidak mempunyai tempat khusus untuk menyimpan bahan makanan dan penjamah makanan juga tidak memakai alat pelindung diri. Pengelolaan makanan dalam proses sanitasi makanan menyangkut banyak faktor mulai dari asal/sumber bahan makanan, proses hingga menjadi makanan, penyajian kepada pembeli dan faktor lingkungan. Pengamatan pada kantin Universitas X Lamongan menunjukkan bahwa tenaga penjamah makanan tidak menerapkan prinsip higiene dan sanitasi. Diantaranya tidak memakai penutup mulut, tidak memakai penutup kepala dan tidak pakai celemek. Berdasarkan uraian di atas maka peneliti tertarik untuk melakukan penelitian mengenai Kualitas Penerapan Higiene Sanitasi (Studi Kasus: Kantin Universitas X Lamongan).

\section{Metode penelitian}

Jenis penelitian ini bersifat penelitian kuantitatif deskriptif analitik dengan variabelvariabel yang diteliti yaitu umur, jenis kelamin, pendidikan, pengetahuan dan lingkungan. Desain yang digunakan dalam penelitian ini adalah cross sectional di mana data variabel bebas dan variabel terikat dibandingkan pada waktu yang sama.

\section{Hasil dan Pembahasan}

\subsection{Distribusi frekuensi responden dan lingkungan}

Berdasarkan variabel yang diteliti frekuensi responden dibagi menjadi umur, jenis kelamin, pendidikan, pengetahuan dan lingkungan, maka dapat dilihat pada tabel di bawah ini:

Tabel 1. Distribusi frekuensi responden dan lingkungan

\begin{tabular}{|lll|}
\hline \multicolumn{1}{|c|}{ Variabel } & $\mathrm{n}$ & $\%$ \\
\hline Umur & & \\
\hline $21-30$ & 3 & $22 \%$ \\
\hline $31-40$ & 2 & $14 \%$ \\
\hline$\geq 40$ & 9 & $64 \%$ \\
\hline Jenis Kelamin & & \\
\hline
\end{tabular}




\begin{tabular}{|lcc|}
\hline Laki-laki & 8 & $57 \%$ \\
\hline Perempuan & 6 & $43 \%$ \\
\hline Pendidikan & & \\
\hline Tidak SMA (SD\&SMP) & 8 & $57 \%$ \\
\hline SMA/MA & 4 & $29 \%$ \\
\hline Perguruan Tinggi & 2 & $14 \%$ \\
\hline Pengetahuan & & \\
\hline Kurang baik & 9 & $64 \%$ \\
\hline Baik & 5 & $36 \%$ \\
\hline Kondisi lingkungan & & \\
\hline Kurang baik & 10 & 67 \\
\hline Baik & 4 & 33 \\
\hline
\end{tabular}

Distribusi frekuensi umur responden di kantin Universitas " $\mathrm{X}$ " Lamongan dapat dilihat dari 14 responden sebanyak $64 \%$ penjual makanan berusia $\geq 40$ tahun, 14\% berusia 31-40 tahun dan 22\% berusia 21-30 tahun. Dengan perincian sebagai berikut : umur $21-30$ tahun sebanyak 3 responden, umur 31 - 40 sebanyak 2 responden dan umur $\geq 40$ sebanyak 9 responden.

Distribusi frekuensi jenis kelamin responden di kantin Universitas " $X$ " Lamongan dapat dilihat dari 14 responden menunjukkan bahwa sebagian besar penjual makanan adalah laki-laki, dengan rincian 57\% (8 responden) laki-laki dan $43 \%$ (6 responden) perempuan.

Distribusi frekuensi tingkat pendidikan responden di kantin Universitas " $\mathrm{X}$ " Lamongan dapat dilihat dari 14 responden menunjukkan bahwa sebagian besar penjual makanan berpendidikan terakhir tingkat SD atau SMP sebesar 57\% (8 responden), 29\% (4 responden) berpendidikan SMA dan 14\% (2 responden) berpendidikan sarjana.

Distribusi frekuensi tingkat pengetahuan responden di kantin Universitas " $X$ " Lamongan dapat dilihat dari 14 responden menunjukkan bahwa sebagian besar penjual makanan memiliki pengetahuan yang kurang baik, dengan rincian 64\% (9 responden) berpengetahuan kurang baik dan $36 \%$ (5 responden) berpengetahuan baik.

Dapat diketahui bahwa dari 14 penjamah makanan di kantin Universitas " $X$ " Lamongan sebagian besar memiliki kondisi lingkungan yang kurang baik, dengan rincian 67\% (10 responden) memiliki kondisi lingkungan kurang baik dan 33\% (4 responden) memiliki kondisi lingkungan yang baik. 


\subsection{Pengaruh Antara Umur dengan Penerapam Higiene Sanitasi}

Berdasarkan penelitian yang telah dilakukan responden berjumlah 14 responden untuk kategori responden menurut umur pada penjamah makanan kantin, terdapat 3 orang (22\%) orang yang memiliki umur antara 21-30 tahun, 2 orang (14\%) orang yang memiliki umur antara 31-40 tahun, 9 orang (64\%) yang memiliki umur antara 41-50 tahun.

Umur dapat mempengaruhi suatu sikap dan perilaku seseorang. Semakin bertambahnya umur diharapkan seseorang bertambah pula kedewasaannya makin mantap pengendalian emosinya dan makin tepat segala tindakannya (Yosvita, 2011). Penelitian Marsaulina (2004) di DKI Jakarta yang menyimpulkan adanya hubungan antara kebersihan perorangan dengan umur penjamah makanan, semakin tinggi umur penjamah makanan maka semakin baik kebersihan penjamah makanan.

\subsection{Pengaruh Antara Jenis Kelamin dengan Penerapan Higiene Sanitasi}

Distribusi frekuensi jenis kelamin responden di kantin Universitas " $\mathrm{X}$ " dapat dilihat dari 14 responden sebanyak 8 orang $(57 \%)$ berjenis kelamin laki-laki dan 6 orang (43\%) berjenis kelamin perempuan. Kantin Universitas " $\mathrm{X}$ " ini merupakan kantin yang buka dari pagi sampai dengan sore. Penjamah makanan di kantin ini harus siap sedia setiap ada pesanan. Hasil dari penelitian ini menunjukkan bahwa dari 14 responden penjamah makanan di kantin Universitas "X” terdapat lebih banyak penjamah makanan yang berjenis kelamin laki-laki.

Hal ini sejalan dengan penelitian Erna (2012) yang mengatakan bahwa penjamah makanan dapat dilakukan oleh semua jenis kelamin, tidak hanya terbatas pada perempuan yang biasanya berprofesi sebagai ibu rumah tangga, namun juga dapat dilakukan oleh laki-laki. Menurut Kusumawati (2010), terdapat perbedaan tingkat produktifitas antara laki-laki dan perempuan, perbedaan tersebut berkaitan dengan ketrampilan, motivasi, dan kemampuan belajar. Hal ini terjadi karena perempuan lebih rentan terhadap kelelahan akibat kerja. Hasil penelitian yang dilakukan oleh Nurtika (2014), menyatakan bahwa tidak ada hubungan antara jenis kelamin dengan perilaku keamanan pangan di Kantin Universitas Gajah Mada.

\subsection{Pengaruh Antara Pendidikan dengan Penerapan Higiene Sanitasi}

Hasil penelitian diketahui bahwa dari 14 responden sebanyak 8 orang (57\%) tidak tamat SMA (SD dan SMP) dan 4 orang (29\%) tamat SMA dan 2 responden (14\%) berpendidikan 
Perguruan Tinggi. Menurut penelitian Wulansari (2013) tentang penyelenggaraan makanan dan tingkat kepuasan konsumen di kantin Zea Mays Institut Pertanian Bogor menyebutkan bahwa pendidikan merupakan faktor yang sangat penting dalam bekerja.

Hal ini disebabkan karena latar belakang pendidikan mencerminkan kecerdasan dan keterampilan tertentu sehingga kesuksesan seseorang yang akan berpengaruh pada penampilan kerja. Semakin tinggi tingkat pendidikan maka akan semakin cenderung sukses dalam bekerja bahkan menurut peneliti karena banyak diantara penjamah makanan di kantin yang berpendidikan tidak tamat SMA karena faktor ekonomi yang mengharuskan mereka untuk bekerja dan tanpa memikirkan sekolah.

Notoatmodjo (2007) mengatakan bahwa semakin tinggi tingkat pendidikan seseorang maka semakin mudah untuk menerima dan menangkap informasi yang dibutuhkan serta akan meningkatkan pula pengetahuannya. Dari teori tersebut, dapat ditarik kesimpulan bahwa pendidikan merupakan salah satu faktor yang dapat mempengaruhi seseorang untuk berperilaku positif. Semakin tinggi pendidikan yang dimiliki maka semakin baik perilaku kepatuhannya. Begitu pula sebaliknya, jika pendidikan yang dimiliki rendah maka kecenderungan untuk berperilaku negatif juga semakin besar. Hasil penelitian yang dilakukan oleh Nurtika (2014), yang menyatakan bahwa tidak ada hubungan antara jenis kelamin dengan perilaku keamanan pangan di Kantin Universitas Gajah Mada.

\subsection{Pengaruh Antara Pengetahuan dengan Penerapan Higiene Sanitasi}

Dapat dilihat dari 14 responden sebanyak 9 orang (64\%) mempunyai pengetahuan tentang pencucian tangan, dan 5 orang (36\%) mempunyai pengetahuan tentang kebersihan pakaian. Pengetahuan yang baik sangat diperlukan dalam kegiatan higiene dan sanitasi dalam proses penyelenggaraan makanan. Pengetahuan dari penjamah makanan juga akan mempengaruhi kualitas makanan tersebut. Hal ini menunjukkan bahwa sudah banyak dari penjamah makanan yang ada di kantin Universitas " $X$ " berpengetahuan baik. Tetapi dari beberapa kuesioner yang di ajukan kepada responden hampir 50\% lebih responden tidak mengetahui bahwa seorang penjamah makanan wajib menggunakan tutup kepala dan celemek saat pengolahan makanan.

Menurut Meikawati (2010), mengatakan bahwa responden mempunyai pengetahuan baik mempunyai jumlah yang paling banyak yaitu 10 orang $(50,0 \%)$, dan yang paling sedikit mempunyai pengetahuan sedang sebanyak 2 orang $(10,0 \%)$. Hal ini menunjukkan bahwa hanya 
sebagian responden yang sudah berpengetahuan baik, sedangkan sebagian lagi belum baik. Penjamah makanan harus optimal dan sesuai dengan mutu pelayanan standar kesehatan. Penyelenggaraan makanan yang kurang memenuhi syarat kesehatan dapat menyebabkan timbulnya penyakit. Hasil suatu penelitian yang dilakukan oleh Swamilaksita (2016), menyatakan bahwa ada hubungan antara pengetahuan dengan penerapan higiene sanitasi di Kantin Universitas Esa Unggul.

\subsection{Pengaruh Antara Lingkungan Dengan Penerapan Higiene Sanitasi}

Berdasarkan hasil yang diperoleh pada tabel 4.6 bisa dilihat bahwa kantin satu mendapatkan nilai sebesar 14,13\%, kantin dua mendapatkan nilai sebesar 9,78\%, kantin tiga mendapatkan nilai sebesar 9,78\%, kantin empat mendapatkan nilai sebesar 10,86\%, kantin lima mendapatkan nilai sebesar $11,95 \%$, kantin enam mendapatkan nilai sebesar 14,13\% dan kantin tujuh mendapatkan nilai sebesar 10,86\% yang menunjukkan bahwa seluruh kantin di Universitas "X" lamongan tidak memenuhi syarat yang mengacu pada Permenkes RI Nomor 1096 Tahun 2011.

Penelitian yang dilakukan oleh Swamilaksita (2016) menyatakan bahwa ada hubungan antara lingkungan dengan penerapan higiene sanitasi di kantin Universitas Esa Unggul tahun 2016. Idealnya, lingkungan sekitar penyelenggaraan makanan harus memiliki kondisi lingkungan yang bersih dan sehat. Menurut Djaja (2003), sanitasi alat yang baik justru menjadi pencegah untuk menghasilkan kualitas bakteriologis makanan yang memenuhi syarat. Hal ini dapat terjadi dikarenakan kualitas bakteriologis makanan yang memenuhi syarat dapat dipengaruhi oleh faktorfaktor lain disamping sanitasi alat, seperti tangan penjamah makanan, kualitas air bersih yang digunakan, lingkungan pengolahan makanan, dan penyajian makanan.

Menurut Notoatmodjo (2007), yang menyatakan bahwa Kondisi lingkungan dapat dilihat dari beberapa hal yaitu halaman kantin yang bersih, tidak ditemukan lalat dan tikus, permukaan lantai yang tidak licin dan mudah dibersihkan, dinding terbuat dari bahan yang kuat, langit-langit berwarna terang dan pencahayaan cukup.

\section{Kesimpulan}

Berdasarkan hasil penelitian yang didapat bahwa faktor umur, jenis kelamin dan tingkat pendidikan tidak mempengaruhi suatu penerapan higine sanitasi di Kantin Universitas " $\mathrm{X}$ " 
Lamongan, tingkat pengetahuan dan kondisi lingkungan kantin dapat mempengaruhi suatu penerapan higine sanitasi di Kantin Universitas " $X$ ” Lamongan.

Acknowledgments: Terima kasih penulis sampaikan kepada seluruh pihak yang terlibat dalam penelitian ini

Conflicts of Interest: The authors declare no conflict of interest

\section{Daftar Pustaka}

Ningsih. (2014). Penyuluhan hygiene sanitasi makanan dan minuman, serta kualitas makanan yang dijajakan pedagang di lingkungan SDN Kota Samarinda. Jurnal Kesehatan Masyarakat.

Nurtika. (2014). Hubungan karakteristik individu dengan perilaku keamanan pangan penjamah makanan di kantin Universitas Gadjah Mada. Jurnal Kesehtan Masyarakat.

Swamilaksita. (2016). Faktor-Faktor Yang Mempengaruhi Penerapan Higiene Sanitasi Di Kantin Universitas Esa Unggul Tahun 2016. Jakarta. 